\title{
Fasfionable Form and Tailor-made Message: Transcultural Approaches to Arabic Script on the Royal Norman Mantle and Alb
}

\author{
Isabelle Dolezalek*
}

\begin{abstract}
This article applies recent methodological approaches to a case study of two Mediterranean objects from Norman Sicily-Roger II's mantle and William II's alb. Approaching the Arabic inscriptions on the royal garments through the methodological frames of 'transfer' and 'shared court culture' allows for an observation of formal relations and continuities across the Mediterranean, although these do not account entirely for the idiosyncrasies of the Norman objects. The comparative approach, on the other hand, and particularly the differences which it reveals between the Norman and other Mediterranean uses of Arabic textile inscriptions, highlights the choices underlying the adaptation of these ornamental motifs to twelfth-century Sicily. I shall argue, therefore, that an assessment of the receptions in medieval Europe of 'transcultural' ornamental motifs, such as Arabic textile inscriptions, greatly benefits from an approach combining methodologies.
\end{abstract}

Arabic writing on a garment belonging to a Christian king? Astonishment or even disbelief is voiced by most visitors who pause to examine more closely the ceremonial garments from Norman Sicily now exhibited in the

\footnotetext{
*Institute of Art History, Free University of Berlin, Koserstraße 20, 14195 Berlin. E-mail: i.dolezalek@fu-berlin.de
}

The Medieval History Journal, 15,2 (2012): 243-268

SAGE Publications Los Angeles/London/New Delfi/Singapore/Wasfington DC DOI: $10.1177 / 097194581201500202$ 
imperial Schatzkammer in Vienna. This astonishment is far from being a simple reaction. It is the result of a number of preconceptions, ones based on ideas of cultural and religious identity and a rigid separation between Christian and Islamic visual cultures. Inscriptions, probably more than any other form of ornament, lend themselves to associations with specific cultural spheres. They are easily defined - or so it seems - by boundaries of language and, in the case of Arabic writing, are commonly understood as related to the geographical spread of Islam. In this sense, a spontaneous reaction of surprise can be seen as the expression of a confrontation between the conventionally established concepts of cultural boundaries, on the one hand, which not only form the modern viewer's experience but have also shaped the frameworks of past art historical investigations, and the reality of these twelfth-century Mediterranean objects from Sicily, on the other.

This article offers reflections on the impact of modern frames of thought on the reception of these Arabic inscriptions in art historical scholarship. ${ }^{1}$ The ideas of 'transfer', 'shared court culture' and 'comparison', in particular, have significantly shaped recent approaches to Mediterranean objects. ${ }^{2}$ The concept of 'cultural transfer', for instance, has entered recent art historical discourse as a means for looking beyond cultural boundaries through an emphasis on mechanisms of interchange and

${ }^{1}$ This article is based on methodological issues encountered in the preparation of my doctoral dissertation. It was written during a stay at the KHI in Florence, to which I was very generously invited by Gerhard Wolf. I would like to extend my sincere gratitude to him and to my supervisors, Vera Beyer and Avinoam Shalem.

${ }^{2}$ Transcultural methodological approaches have come under close scrutiny in recent historical studies. This applies to comparative approaches in particular, which have been criticised for working with the problematic assumptions that there are 'universal' categories and separate, homogeneous cultural entities. See Espagne, 'Sur les limites du comparatisme en histoire culturelle'; Werner and Zimmermann, 'Vergleich, Transfer, Verflechtung'. The methodological challenges of applying ideas such as 'transcultural comparison', or 'entangled history' to art history, on the other hand, are prominently addressed in the work of Vera Beyer (Tagungsbericht Transkulturelle Geschichte der Vormoderne - Eine Bestandsaufnahme. 13-14 February 2009, Basel, in: H-Soz-u-Kult, April 2009, http://hsozkult.geschichte. hu-berlin.de/tagungsberichte/id=2572). A very sophisticated example of transcultural art history, in its application to the material cultures of Muslim and Hindu contexts, is provided by Flood, Objects of Translation.

- The Medieval History Journal, 15, 2 (2012): 243-268 
processes of reception. ${ }^{3}$ Oleg Grabar's thesis of a 'shared court culture of objects in the medieval Mediterranean', on the other hand, transcends cultural and stylistic classifications through acknowledging the existence of a Mediterranean unity with a common aesthetic. In this article, both the explanatory power as well as the limits of these concepts will be evaluated in relation to the interpretation of Arabic inscriptions on the Norman garments. I will argue that approaching the Norman objects through the notions of 'transfer' and 'shared court culture' alone poses the risk of restricting the study of their written ornaments to purely formal considerations, whereas the comparative approach also offers the possibility of examining the role of the inscriptions within a given social context.

\section{Introducing the Objects}

Three of the garments preserved in Vienna and associated with the Norman and Svevian courts of Sicily carry Arabic inscriptions, while another two inscribed textiles are documented among the finds of the royal tombs in the cathedral of Palermo. ${ }^{4}$ For the sake of clarity, however, only two of these pieces will figure in the present discussion: Roger II's mantle and William II's alb. The stylistic, iconographical and technical complexity of the mantle and alb provide a visual summary of the multicultural implications of the study of the art and artefacts of Norman Sicily; the appearance of Arabic writing on the garments of the Norman-Christian kings is particularly representative of these implications.

The famous mantle with its long Kufic inscription was produced during the reign of Roger II (b. 1095/d. 1154 AD); it is a highly exceptional piece

\footnotetext{
${ }^{3}$ For a historiographical overview and definition of 'transfer' in its application to the history of the medieval Mediterranean, see Abdellatif et al., 'Introduction à l'étude des transferts culturels en Méditerranée médiévale'.

${ }^{4}$ The garments with Arabic inscriptions preserved in Vienna include Roger II's mantle as well as the ceremonial stockings and the alb associated with King William II. For a 'biography' of these garments, see Bauer, 'Geschichte der sizilischen Gewänder'. A crown with inscribed textile bands was found in the sarcophagus of the Emperor Henry VI. Frederick II's funerary garments include an alb with Arabic inscriptions. See the illustrated Daniele, I regali sepolcri (available online at: http://digi.ub.uni-heidelberg. de/diglit/daniele1784).
}

The Medieval History Journal, 15, 2 (2012): 243-268 
and has received much scholarly attention from historians of both Islamic and European art (Figure 1). ${ }^{5}$ The general shape of the semi-circular mantle follows the tradition of Byzantine and Latin liturgical dress. A Byzantine provenance has been proposed for its woven red samite base fabric, while the mantle's gold-embroidered ornamentation, with its prominent Arabic inscription and unusual iconography is reminiscent of the work of artisans trained in the Arab tradition. ${ }^{6}$ The mantle's ornamental scheme is organised along two halves, which are separated by a centrally placed, stylised tree constituting the vertical axis along which the main, mirrored iconographical motif - a lion restraining a camel-is laid out. The continuous Kufic inscription, embroidered on the full length of the mantle's hem, provides a frame for the largescale figural ornaments and acts as a unifying element between the two symmetrical halves of the mantle. The inscription begins and ends with information about the production of the mantle: the date of manufacture

\section{Figure 1}

Norman Mantle, 1133/34 AD. Vienna, Kunsthistorisches Museum

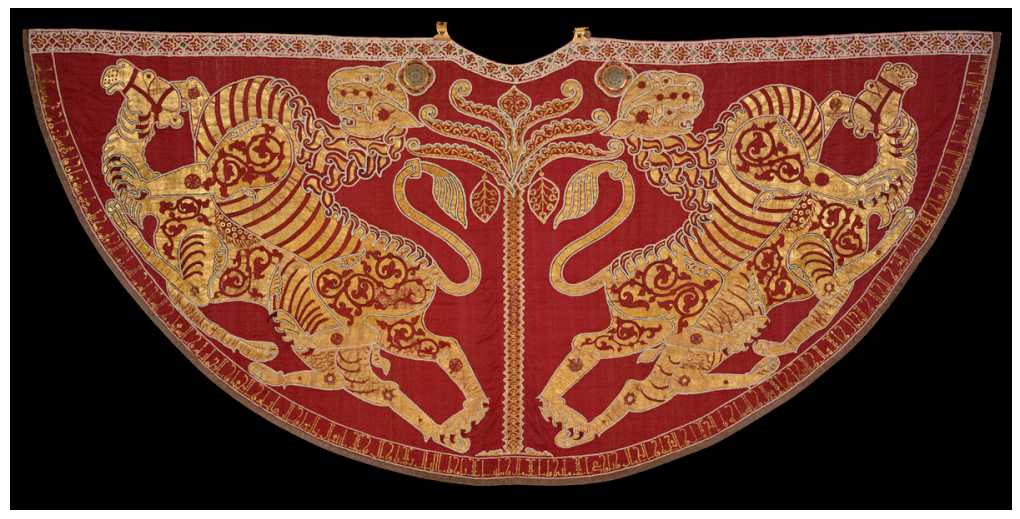

${ }^{5}$ A precise technical description of the mantle is given in Nobiles Officinae: cat. 66. For a good bibliographical overview, see Grabar, 'The So-called Mantle of Roger II': 44-48.

${ }^{6}$ Jacoby, 'Silk in Western Byzantium': 464; Monneret de Villard, 'La tessitura palermitana sotto i Normanni'; Bauer, 'Der Mantel Rogers II': 116. For a summary of different interpretations of the iconography and their proposed relationship to ancient Eastern prototypes, see Rotraud Bauer's catalogue entry in Nobiles Officinae: cat. 66.

- The Medieval History Journal, 15, 2 (2012): 243-268 
is given as $528 \mathrm{AH}(1133 / 34 \mathrm{AD})$ and Palermo (madinat Siqillīya) is named as the place where it was made. ${ }^{7}$ The main body of the text, however, written in a form of rhymed prose known as $\mathrm{saj}^{6}{ }_{,}^{8}$ contains a long enumeration of the qualities of the royal workshop, probably to be read as an emblematic reference to the splendour of the Norman kingdom in general. ${ }^{9}$ With the exception of its lining, which is made up of textiles of different periods and origins, ${ }^{10}$ the mantle is remarkable for its overall compositional unity.

The alb of William II (b. 1155/d. 1189 AD), in contrast, is an assemblage of various silken textiles with gold-embroidered ornaments, precious stones and pearls; its textile components are usually considered on stylistic grounds to have been produced under the rule of several Norman and

\footnotetext{
${ }^{7}$ My deliberately literal translation is based on the Arabic transcriptions by Al-Samman 'Arabische Inschriften': 34 and Johns, 'Die arabischen Inschriften der Normannenkönige Siziliens': 48. The indications of the literary structure are taken from Johns.

Mimmā 'umila bi-l-khizānat/al-malakīya al-ma'mūra/bi-l-sa'd wa-l-ijlāl/wa-l-jadd wa-l-kamāl / wa-l-țawl wa-l-ifḍāl / wa-l-qabūl wa-l-'iqbāl / wa-l-samāha wa-l-jalāl / wa l-fakhr wa-l-jamāl / wa-bulūgh al-amān(ī?) wa-l-āmāl / wa țīb al-ayyām wa-l-layāl / bi-lā zawāl wa lā intiqāl / bi-l- 'izz wa-l-di'aya / wa-l- hifẓ wa-l- himāya / wa-l-sa'd / wa-l-salāma / wa-l-nașr wa-l-kifäya / bi-madīnat Șiqillīya / sana thamān wa- 'ishrīn wa-khamsmā'ia.

Of what was made in the khizāna (chamber, treasury), regal and plentiful, with happiness and honour, and good fortune and perfection, and long life and profit, and welcome and prosperity, and generosity and splendour, and glory and beauty, and realisation of desires and hopes, and delights of days and nights, without end and without modification, with might and care, and sponsorship and protection, and happiness and well-being, and triumph and sufficiency. In the city of Sicily, in the year 528.
}

For another English translation of the inscription, as well as some grammatical details, see Grabar, 'The So-called Mantle of Roger II': 39. I would like to thank Dorothea Köhler for her patient linguistic explanations.

${ }^{8}$ Both Al-Samman and Johns mention the literary form. Al-Samman, 'Arabische Inschriften': 34 and Johns, 'Die arabischen Inschriften der Normannenkönige Siziliens': $37-59,48$.

${ }^{9}$ This is suggested by Tronzo, who reads the inscription of the mantle as 'a description of the state of life under the rule of King Roger-a perfected earthly existence'. Tronzo, 'The Mantle of Roger II': 241-54, 243.

${ }^{10}$ Some of the textiles, such as the intriguing tapestry-woven figured silks may predate the embroideries. Others were clearly added at a much later period. Nobiles Officinae: cat. $66,263$. 
Svevian kings (Figure 2) ${ }^{11}$ These decorative textiles include cuffs and embroidered bands attached to both sleeves of the alb, a large breast panel and the inscribed hem that is the focus of this article. The shape of the garment clearly derives from Christian tradition. As is the case with the mantle, however, there is firm evidence of the involvement of Arab craftsmen in the production of the alb, not only because of the presence of the bilingual Arabic-Latin inscription on its hem, but also because

\section{Figure 2}

Norman Alb, late twelfth century. Vienna, Kunsthistorisches Museum

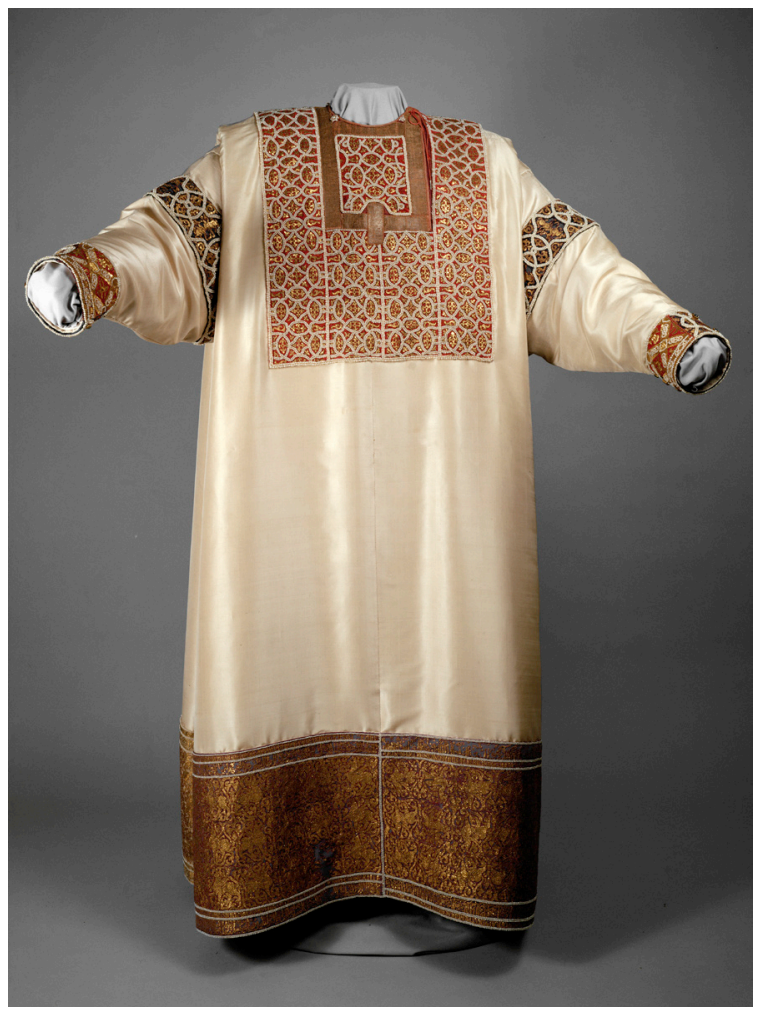

${ }^{11}$ Nobiles Officinae: cat. 68. The embroidered textiles from the medieval period are presently mounted on what appears to be an eighteenth-century white silk fabric.

- The Medieval History Journal, 15, 2 (2012): 243-268 
of the recently discovered, handwritten notes in Arabic hidden in the sleeves (the content of these relates to practicalities of production). ${ }^{12}$ The hem's bilingual inscription is perfectly legible, despite its small size. It is repeated twice on each of the four gold-embroidered pieces making up the hem. The Latin inscription dates the embroidery to the fifteenth year of William II's reign - 1181 AD — as stated again in the Arabic inscription, while the 'felicitous city of Palermo' (in the Latin inscription) and the 'plentiful khizāna' (al-khizāna al-ma 'mūra) (in the Arabic) are identified as the place of manufacture. ${ }^{13}$ William II is mentioned explicitly in both inscriptions, as are the territories under his rule and his titles, though with varying degrees of legal accuracy and literary flourish.

\section{Writing on a Ruler's Robes}

It is very rare for a courtly textile from the medieval West to include an inscription unrelated to the iconography of the piece. There are a few significant exceptions, such as the mantle of Emperor Henry II, which has a long embroidered inscription in Latin independent from the tituli

${ }^{12}$ For a transcription and discussion of these notes, see Al-Samman, 'Arabische Inschriften': 10-19 and Johns, 'Die arabischen Inschriften der Normannenkönige Siziliens': 53.

${ }^{13}$ Latin inscription (as quoted in Nobiles Officinae: cat. 68):

Operatv [m] felici vrbe Panormi XV anno regni d[omi]ni W[illelmi] d[e] i gra[tia] regis Sicilie dvcat [vs] Apulie et principat [vs] Capve filii regis W[illelmi] indictio[n]e XIII.

Made in the felicitous city of Palermo in the fifteenth year of the reign of lord William, through God's grace King of Sicily, of the Duchy of Apulia and of the Principality of Capua, in the thirteenth indiction.

Arabic inscription (transliteration and translation based on Al-Samman, 'Arabische Inschriften': 22).

Mimmā 'amara bi-'amalihi al-malik al-mu'azzam Ghulīyālm al-thānī al-musta 'izz billah, al- mu 'taḍid bi-qudratihi, al-mustanșir bi-qūwatihi mālik İțālīya wa Ankuburda wa Qalūrīya wa Șiqillīya, mu 'izz' imām R(ü)mīya, al-nāṣir li-l-millat al-nașrānīya, bi-khizānatihi al-ma 'mūra bi-dūwām al- 'izz min tārīkh (ūlìyān?) al-rābi' 'ashr sanat 'alf wa mā'ia (wa) wāhid wa thamānīn li-tārīkh sayīdnā Yasū 'a al-masīh.

From what was ordered to be made by the magnificent King William the second, honoured through God, supported through His power, victorious through His force, ruler of Italy and Ankuburda and Qalauria and Sicily, supporter of the Imam of Rumiya, protector of the Christian faith, in his plentiful khizäna (chamber, treasury) of lasting glory, in the time of the $14^{\text {th }}$ Ulian (?), in the year 1181 of the time of our Lord Jesus the Messiah.

The Medieval History Journal, 15, 2 (2012): 243-268 
referring to its motifs,,${ }^{14}$ but these do not detract from the fact that the inscribed Norman garments from Sicily ought to be considered as a highly unusual group within the context of Latin-Christian kingship. The fact that most of these inscriptions are in Arabic is another significant detail that emphasises the exceptional status of these garments, the visual appearance of which bears witness to multiple underlying movements of cultural exchange. While Arabic inscriptions were not part of the formal repertoire of European textiles, such ornamental inscriptions are very commonly found on contemporary textiles from regions under Islamic rule.

The most frequently studied group of inscribed Islamic textiles consists of țirāz textiles, which are inscribed with the name of the ruler. ${ }^{15}$ Tirā $z$ inscriptions usually consist of a single or double line of Arabic script, either woven or embroidered onto a base fabric, which could then be turned into, or applied to a garment. ${ }^{16}$ The content of these inscriptions is highly standardised, commencing with the basmallah and a few invocations, then proceeding to mention the name and titles of the reigning caliph, and usually conferring blessings and good wishes on him. Many inscriptions then give the name of additional individuals involved in the production of

${ }^{14}$ Studies on the so-called Star Mantle of Henry II include O'Connor, 'The Star Mantle of Henry II'; Enzensberger, 'Bamberg und Apulien'.

${ }^{15}$ Due to their relevance as textual sources, tirāz textiles with historical inscriptions are among the most published inscribed Islamic textiles. Nevertheless, there is a large proportion of other types of inscribed textiles, particularly those carrying religious formulae and blessings. Al-Qalqashandi, for example, mentions the use of textiles with religious inscriptions in Fatimid Egypt. On specific Fridays during the month of Ramadan, two curtains with clear and exact letters in red silk were hung up on either side of the mihrāb of the mosque of Al-Hakim (the chapters of the Opening and Friday on the right hand curtain and the Opening and the Hypocrites on the left hand curtain). See Al-Qalqashandi, Institutions des Fâtimides: 38.

Fīal-sitr al- 'aīman maktūb bi-raqm ḥarīr 'ahmmar sūrat al-fātiḥa wa sūrat al-jumm 'a, wa fì al-sitr al- 'aīsar sūrat al-fātiha wa sūrat al-manāfiqūn, kitāba wādiha maụbūṭa.

${ }^{16}$ For an example of an Abbasid tunic (Inv. n. A6 bis, Bardo Museum, Tunis) inscribed with blessings, see http://www.discoverislamicart.org/database_item.php?id=object;ISL;t n;Mus01_A;47;en.

Two additional examples of complete tirāaz textiles, Fatimid in this case, are kept in the church treasuries of Cadouin and Apt. Delluc/Delluc, 'Le suaire de Cadouin'. We can deduce from the material and illustrations in manuscripts, notably the Paris Maqamat (Bibl. Nat., ms. arabe 5847), that the tirāz inscriptions would usually have adorned the upper-sleeves, cuffs or the back of the garments.

- The Medieval History Journal, 15, 2 (2012): 243-268 
the textile, followed by a reference to the place and date of production. ${ }^{17}$ The workshops in which inscribed tirāz textiles were produced were of two

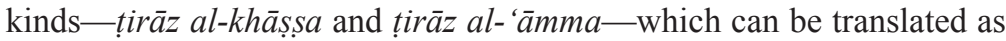
'private' and 'public' tirāzz, respectively. While the public tirāz is generally said to have produced for the open market and the private tirāz for the needs of the caliph and his court, the actual definition is far more complex and continues to be a subject of scholarly controversy. ${ }^{18}$

In the Islamic courts of the medieval Mediterranean, these so-called tira $\bar{z} z$ textiles were distributed to courtiers and individuals of particular merit or used as diplomatic gifts; they seem to have played an important role in spreading political propaganda. ${ }^{19}$ The garments, and more particularly their inscriptions, were a marker of the caliphs' political and religious authority. The widespread presence of inscriptions on the garments of the ruling elite was thus a phenomenon with a strongly political connotation. ${ }^{20}$ The political function of inscribed textiles is something that, I believe, also applies to the Norman garments, which are clearly associated with the royal court and ceremony. Despite the actual difference in content between a standard tirāz and the inscriptions on the Norman mantle and alb, the proximity of Norman practice to the Islamic tradition is undeniable.

Before the Norman conquest, Sicily had been under Islamic rule for almost 200 years (827-1061 AD), ${ }^{21}$ initially as an outpost of Abbasid rule and, later, as an ally of the Fatimid dynasty. However, the possibility that there was a simple Norman takeover of a tirāz workshop in Sicily that may have been active during Arab rule can be discarded. There is no material evidence of textiles with tirāz inscriptions from Islamic Sicily. ${ }^{22}$ Furthermore, although the sources attest to the commercial production of silk textiles in Islamic Sicily, they do not provide any evidence for

${ }^{17}$ For examples of transcribed and translated inscriptions, see Bellinger and Kühnel, Catalogue of Dated Tiraz Fabrics.

${ }^{18}$ For a bibliography and critical analysis of literature on both institutions, see Sokoly, 'Early Islamic Textile Institutions'.

19 'Țirāz', Encyclopaedia of Islam, Second Edition (EI 2). On political connotations of Islamic robing ceremonies, see Sanders, 'Robes of Honor in Fatimid Egypt'.

${ }^{20}$ This point is raised with particular emphasis on the Fatimid period by Biermann, 'Art and Politics' and ibid, Writing Signs.

21 'Șikilliya', EI 2.

${ }^{22}$ Monneret de Villard, 'La tessitura palermitana sotto i Normanni'; Jacoby, 'Seide und seidene Textilien im arabischen und normannischen Sizilien': 68.

The Medieval History Journal, 15, 2 (2012): 243-268 
the existence of the kind of state-run tirāz workshops described in the foregoing. ${ }^{23}$ There is, of course, a risk in drawing firm conclusions from an absence of evidence. Nevertheless, it would be astonishing, given the great prestige of the tirīa $z$ institutions, for them to have been omitted from the remaining eyewitness accounts of Islamic Sicily. ${ }^{24}$ Furthermore, there is an important terminological difference that clearly sets apart the Norman royal workshop from even the contemporary Arab tirāz institutions of the twelfth century. As was seen earlier, the place where both the mantle and the alb were produced is called the khizanna al-ma'müra in the inscriptions, not a tir $\bar{a} z .{ }^{25}$ This fundamental difference between Norman and Arab practice is all the more surprising in view of Roger II's great interest in contemporary Arab institutions, which was demonstrated by his reintroduction of an Arabic administrative system to the Sicilian chancery in the $1130 \mathrm{~s}^{26}$

So, while the Normans certainly employed local, Arabic-speaking artisans who would have brought their knowledge of forms and techniques to the courtly workshops, the transfer underlying the prominent use of Arabic inscriptions on the alb and mantle was not an intra-cultural or trans-historical one, consisting of the takeover by the occupiers of a pre-existing tradition. Instead, it is representative of the importation and adaptation of a contemporary Arab tradition into the Norman sphere. We should therefore ask what the recognition of such an intercultural transfer entails for the interpretation of the mantle and alb.

${ }^{23}$ Jacoby, 'Seide und seidene Textilien im arabischen und normannischen Sizilien': $61-73$.

${ }^{24}$ Ibid: 61 . The tenth-century travellers Ibn Hawqal and Al-Muqaddasi do not mention a Sicilian silk production pre-dating the Norman conquest.

${ }^{25}$ Khizāna, which derives from the root khazana (to store, amass, keep secret), is best imagined, in accordance with Johns' suggestion, as a store combined with a workshop similar to the Fatimid khizānat al-bunūd (khizāna of the flags or banners). Johns, 'Die arabischen Inschriften der Normannenkönige Siziliens': 48. A țirāz workshop could, of course, be part of a larger khizāna; however, Islamic textile inscriptions refer to the term țirāz. Ma 'amūra, on the other hand, derives from 'amara (to inhabit, people, flourish) and is used as an epithet to refer to royal institutions. See Johns, Arabic Administration: 195.

${ }^{26}$ Johns argues for an importation of Fatimid administrative practice to Norman Sicily. Johns, Arabic Administration. See also Bresc and Nef, 'Les actes en arabe dans la Sicile d'époque normande'.

- The Medieval History Journal, 15, 2 (2012): 243-268 


\section{Arabic Writing Abroad}

There are a number of studies dealing with the appearance of Islamicate forms in Europe. Some of them focus on tracing the biographies of objects which originated from Islamic regions and were subsequently used and preserved in Christian contexts. ${ }^{27}$ Others are more concerned with listing and analysing objects or monuments of European manufacture that were clearly inspired by Islamicate forms.$^{28}$ Arabic script, or pseudo-script, on non-Arabic and non-Islamic artefacts has frequently been cited as an example of 'influence' or, more recently, of 'cultural transfer' across confessional boundaries.

The articles by Erdmann and Spittle, both published in 1953, on the use of Arabic writing as an ornament in what is referred to as 'Occidental' or 'Christian' medieval art, respectively, attempt to deal with the transposition of Arabic as an ornamental motif into European contexts. ${ }^{29}$ Erdmann's rigorously formalist catalogue of Kufesque ornament in medieval European art follows a chronological structure, within which ornamental motifs of Kufic inspiration are classified according to their provenance and the different media on which they appear. Spittle, on the other hand, focuses on legible Kufic inscriptions in Christian art, including examples from Byzantium, and discusses the models for this type of ornamentation and its possible meaning. The main questions addressed are whether or not the writing is legible; whether stylistic considerations make it possible to trace the origin of the ornament; to what extent Arabic writing ought to be considered an ornament with an inherently religious Islamic character, and, if so, how this was bypassed in Christian art; and whether Arabic writing had any particular connotations.

These problems surrounding the reception of Kufic and Kufesque forms in Europe are, of course, important. The grouping in both studies of extremely varied material is, however, highly problematic in that it implicitly promotes an assumption that Arabic writing would have been used and perceived in the same way everywhere: the studies focus on the Arabic inscriptions as an isolated motif, instead of analysing each case individually. The collected Kufesque forms and inscriptions are thus dissociated entirely

\footnotetext{
${ }^{27}$ See for example, Shalem, Islam Christianized.

${ }^{28}$ Contadini, 'Artistic Contacts'; Fontana, 'Epigraphic Characters of Islamic Derivation'.

${ }^{29}$ Spittle, 'Cufic Lettering in Christian Art'; Erdmann, 'Arabische Schriftzeichen als Ornamente in der abendländischen Kunst'.
}

The Medieval History Journal, 15, 2 (2012): 243-268 
from the objects and monuments which they adorn, as well as from their broader socio-historical context. A second problem with this approach is its dependence upon clearly traceable boundaries between the place of origin of this particular motif and the context of its reception. Both authors explicitly exclude examples from Sicily, modern Spain and Southern Italy, places where the boundaries were no longer clear-cut. ${ }^{30}$

Studying the Norman garments' Arabic inscriptions using the concept of transfer, on the other hand, shifts the emphasis away from a model of two static entities linked through 'influence' to the processes underlying the intercultural exchange leading to the inscriptions. The concept of transfer, which has recently been applied to the study of the medieval Mediterranean, particularly in French and German scholarship, can be used as a framework showing elements of 'otherness' to be key parts of cultural identity, by emphasising active reception and adaptation. ${ }^{31}$ There are three components to the idea of transfer: the transferred 'object', characterised by its mobility; 32 the spaces within which the object is transferred; and the transferring agents. Concentrating on transfer, on the different identifiable processes of transmission of Arabic written ornament and on its integration into the Norman aesthetic idiom, is a means of accounting for the visual complexity of the Norman objects, without necessarily having to identify specific sources of 'influence'. It also highlights the complexity of Sicilian society itself, in which several cultures interacted.

Indeed, the alb's bilingual inscription alone can be considered as an embodiment of varying parallel layers of transfer. The object transferred is the ornamental script, more precisely, a type of Arabic cursive script (thuluth) reminiscent of the Ayyubid style. ${ }^{33}$ Its presence on William II's alb visualises a transfer of an ornamental form between two cultural spheres: a rather indefinite Arabo-Islamic sphere in which the motif originated, and the multilingual Norman-Christian court of Sicily where it was

${ }^{30}$ Erdmann refers to these regions as areas with an Arabic-European Mischkultur, while Spittle calls them 'outposts of Moslem culture in Europe'. Erdmann, 'Arabische Schriftzeichen als Ornamente in der abendländischen Kunst': 467; Spittle, 'Cufic Lettering in Christian Art': 138.

${ }^{31}$ Abdellatif et al., 'Introduction à l'étude des transferts culturels en Méditerranée médiévale'. The concept of cultural transfer is derived primarily from Michel Espagne. See Espagne Les transferts culturels franco-allemands.

${ }^{32}$ For the role of mobility in the shaping of a Mediterranean visual idiom, see Hoffman, 'Pathways of Portability'.

${ }^{33}$ Al-Samman, 'Arabische Inschriften': 22.

- The Medieval History Journal, 15, 2 (2012): 243-268 
received, ${ }^{34}$ adapted and even 'translated' through its juxtaposition with a Latin inscription. Both objects and people acted as agents transferring the motif. And objects from Islamic regions are known to have been in circulation between the different Mediterranean courts and cultures. It is therefore likely that inscribed, portable objects would have brought this particular motif to the workshops of Norman Sicily. ${ }^{35}$ Moreover, the alb's inscription can be considered as the product of another type of agency, namely that of the artisans, probably Arabs, responsible for the conception and technical execution of the embroidery's ornamental scheme in the Norman king's workshop. ${ }^{36}$

Focusing particularly on Roger's mantle, Eva Hoffman discusses the possible intentions behind the active appropriation of Arabic script in the Norman court of Sicily. She proposes to interpret this ornamental motif as a recognisable sign of the Norman king's cosmopolitanism and of the 'reversal of power' in Sicily: the inscription was intended to show that 'Roger's control and mastery extended to the language and culture of his adversaries ${ }^{37}$ This interpretation is highly plausible, yet it assumes that an Arabic inscription was a 'sign of Islamic culture' ${ }^{38}$ As such, it comes to stand between two separate cultural entities, defined by religious affiliation and personified by, on the one hand, the Latin-Christian king, and his Muslim subjects and predecessors, on the other. However, cultural boundaries appear to have been blurred not only at the Norman court, where Arabic language and culture - though perhaps not Islam — were very present, ${ }^{39}$ but also in the

${ }^{34}$ The Arabic facet of the Norman court is particularly emphasised by Johns, Arabic Administration: Chapter 11.

${ }^{35}$ On the role of objects as the agents of transfer, see Hoffman, 'Pathways of Portability'; Knipp, 'Some Aspects of Style and Heritage in the Norman Stanza'. The specific role of textiles in the transmission of ornamental motifs is addressed in Golombek, 'The Draped Universe of Islam'.

${ }^{36}$ Al-Samman, 'Arabische Inschriften': 10.

${ }^{37}$ Hoffman, 'Pathways of Portability': 32. See also Johns, 'Iscrizioni arabe nella Cappella Palatina': 354. 'L'uso dell'arabo in queste iscrizioni regali voleva far intendere come prima, e più importante nozione che il re padroneggiava la lingua araba. In realtà, è quasi certo che Ruggero non fosse in grado di leggere o scrivere in arabo e che fosse solamente l'uso dell'arabo su monete, documenti e iscrizioni a creare l'illusione che sapesse farlo.'

38 'Beyond the legibility and authenticity of the text, the Arabic script was recognized in the first place as the sign of Islamic culture.' Hoffman, 'Pathways of Portability': 33.

${ }^{39}$ See ibid: 32, and Johns, Arabic Administration: Chapter 9 on the presence of 'palace Saracens' at the Norman court.

The Medieval History Journal, 15, 2 (2012): 243-268 
workshop the royal garments were produced. ${ }^{40}$ This prompts us to envisage an alternative approach to the garments' Arabic inscriptions. Oleg Grabar's thesis of a shared culture of objects in the medieval Mediterranean courts, discussed in the following, opens up new ways of studying the inscribed mantle and alb in full acknowledgement of their multicultural sources, as the representatives of a visual culture untrammelled by religious connotations and cultural boundaries.

\section{A Mediterranean Taste}

Grabar's thesis of a shared court culture in the medieval Mediterranean is an attempt to account for the existence of a number of high quality objects which have similar visual characteristics, which do not openly display any religious affiliation and which cannot clearly be attributed to any particular court of the medieval Mediterranean. ${ }^{41}$ According to Grabar, the circulation of these objects facilitated the creation and spread of a Mediterranean aesthetic and taste, in which Christian or Islamic provenance had no or only little importance. Indeed, the idea of a shared Mediterranean culture means that objects can be categorised by the social status of their owners, for instance, rather than religious or cultural appurtenance. In purely aesthetic terms therefore, Grabar's thesis implies that the presence of Arabic writing on the garments of a Christian king should not be considered unusual. In the frame of this common visual idiom of the elites, 'foreign' motifs, such as Arabic writing, could be freely adapted in Latin contexts. The use of textiles inscribed with Arabic blessings in the royal tombs of the monastery of Las Huelgas, for instance, is further evidence supporting the hypothesis. ${ }^{42}$

Freeing stylistically hybridised objects from the search for their origins has also paved the way for contextual studies in which objects

${ }^{40}$ The presence in the royal workshops of both Arab and Greek artisans is attested at the latest after the 'transfer' — or rather the abduction for their technical expertise — of Greek weavers in 1147. Jacoby, 'Seide und seidene Textilien im arabischen und normannischen Sizilien': 64-65.

${ }^{41}$ For the most complete exposition of this concept, see Grabar, 'The Shared Culture of Objects'. A critical overview of literature using Grabar's concept can be found in Tronzo, The Cultures of his Kingdom: 134-35 and ibid, 'Regarding Norman Sicily'.

${ }^{42}$ Feliciano, 'Muslim Shrouds for Christian Kings?' The question of the extent to which court culture can be separated from religious culture and whether this court culture can or should be limited to the Mediterranean are important but exceed the scope of this article.

- The Medieval History Journal, 15, 2 (2012): 243-268 
such as the mantle and alb can be analysed within the setting of their local production and use. As shown by William Tronzo's recent article on Roger II's mantle, the benefits of such a 'site-specific reading' are clear. ${ }^{43}$ Tronzo's proposition is to study the mantle as a whole, laying particular emphasis on the relationship between the inscription and the iconography. Tronzo ignores the origins of the different motifs and instead looks at its ornamentation within the context of its use at the Norman court of Sicily, seeking to fit the mantle's imagery into a larger tradition. He compares the mantle's iconography with Norman representations of idealised gardens on coins, in mosaics and manuscript illumination and with Roger II's decorative programme in the royal palace and chapel. ${ }^{44}$ Finally, Tronzo demonstrates that the arts of the Norman court, including the iconography and inscription of Roger's mantle, all aim to present the king as a rightful — and an ideal—ruler at a crucial time, shortly after the proclamation of the Norman kingdom, in $1130 \mathrm{AD} .{ }^{45}$

Nevertheless, although acknowledging a shared court aesthetic allows for interpretations of the mantle's inscription, such as Tronzo's, in which the local context of its use prevails over its possible external connotations, this approach is unable to account for the fact that the mantle's political message was delivered not only through the intermediary of an idealising representation of nature, but also through the Arabic language with its very idiosyncratic form. In fact, the intentions behind this choice cannot be fully assessed within the methodological frame of a shared Mediterranean courtly taste: using this frame alone risks reducing the inscriptions on the Norman royal garments to the status of an appealing, but functionless ornament. Of course, we cannot assume that the inscriptions on the mantle or alb would necessarily have been read. The writing is small and difficult to decipher, and it would have been still harder to read when the garments were being worn. ${ }^{46}$ Nevertheless, the writing is legible, highly

${ }^{43}$ Tronzo, 'The Mantle of Roger II': 244.

${ }^{44} \mathrm{Ibid}$ : 249 . The wording of the inscription and the iconography of the mantle can also be related to the painted ceiling of the Cappella Palatina. See Johns, 'Die arabischen Inschriften der Normannenkönige Siziliens': 51.

${ }^{45}$ Tronzo, 'The Mantle of Roger II': 250.

${ }^{46}$ Johns, 'Iscrizioni arabe nella Cappella Palatina': 353. 'Per esempio il testo della lunga iscrizione araba ricamata in oro sull'orlo del mantello di Ruggero poteva essere letto solo se il mantello era esposto completamente aperto, come oggi nella Weltliche Schatzkammer del Kunsthistorisches Museum di Vienna. Nel XII secolo, forse solo chi disegnò il mantello e chi lo ricamò, oltre ai servitori che si occupavano nel guardaroba reale, poté leggere l'iscrizione.'

The Medieval History Journal, 15, 2 (2012): 243-268 
individualistic and reveals a degree of sophistication which would be entirely unnecessary if the presence of writing on the Norman royal textiles merely reflected a formal transfer justified by a shared courtly taste. This suggests that, at least at the level of the production of these garments, particular attention was paid not only to the form, but also to the content of these inscriptions. I would like to emphasise, therefore, that the adoption of this type of ornament on the Norman mantle and alb was definitely a conscious choice. The question, however, is the extent to which this choice may have been motivated not only by an aesthetic appropriation or appreciation, but also by more specific knowledge of the function of textile inscriptions in Islamic contexts.

\section{The Comparative Approach}

It is at this point that comparing the Norman garments with inscribed textiles from Islamic regions of the time offers a valuable complementary approach. In order to demonstrate the possibilities of this method, I intend to compare aspects of the form and function of textile inscriptions in Norman Sicily and Fatimid Egypt. Asking how a specific ornament functions in a specific context, both in visual terms and within its broader cultural environment, counterbalances purely formal approaches. Although there were important institutional differences at the level of production, as we have seen, inscribed textiles were made for both the Norman and Fatimid courts and formed part of an elaborate visual system of political display. ${ }^{47}$ The following observations will consistently depart from the Norman material, in which, once again, the mantle and alb shall be at the focus of attention.

In visual terms, the formal juxtaposition of Latin and Arabic inscriptions on the embroidered hem of the alb reflects the multilingual, multicultural character of Norman Sicilian society. There was a similarly heterogeneous population in Fatimid Egypt, where an Arabic-speaking Ismaili-Shiite minority ruled over what was (initially) a Coptic-Christian region, and there was a similar use of bilingual inscriptions, in Coptic and Arabic, on textiles

\footnotetext{
${ }^{47}$ The present focus on the political functions and connotations of written ornament is not meant to suggest that this was the only possible function for Arabic textile inscriptions. In fact, the more mystical, sacred or apotropaic connotations and functions of Arabic inscriptions have been discussed, especially with regard to the use of inscribed textiles as burial shrouds. Sokoly, 'Between Life and Death'. See also Aanavi, 'Devotional Writing' or Hoffman, 'Pathways of Portability': 33.
}

- The Medieval History Journal, 15, 2 (2012): 243-268 


\section{Figure 3}

Shawl with a Coptic-Arabic bilingual inscription, tenth century. New York, Metropolitan Museum of Art

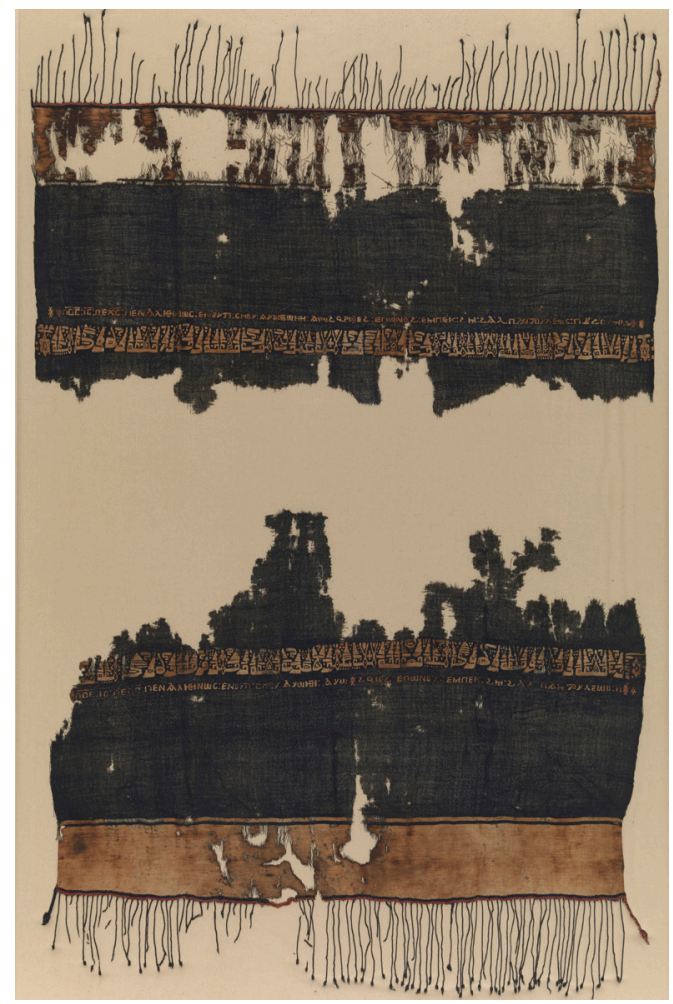

from the Egyptian Fayyum (Figure 3). ${ }^{48}$ However, an important difference between Fatimid and Norman practice has to be pointed out here. In contrast to the Norman alb, the Fayyumic bilingual tir $\bar{a} z$ were produced for private

${ }^{48}$ Dating the small group of bilingual Fayyumic textiles is difficult in the absence of precise references in their inscriptions. While some examples may slightly predate the Fatimid era (as has been suggested in Durand and Rettig, 'Le tirāāz privé de Ṭtūūn'), a later date, corresponding to the early Fatimid period, is proposed in Van der Vliet, 'In a Robe of Gold': n. 48. Given, however, that the Fayyum remained a very active region for textile production, we may assume that bilingual textiles of a comparable type were still produced there under the Fatimids. On the importance of the Fayyum region, see Serjeant, Islamic Textiles: 153-56.

The Medieval History Journal, 15, 2 (2012): 243-268 
patrons. There are, in fact, no known bilingual textile inscriptions originating from the Fatimid court, or, to my knowledge, from any other contemporary Islamic court. Consequently, the presence of a bilingual inscription on William II's alb is a peculiarity that cannot be explained by the reference to a shared Mediterranean court culture: it is clearly indicative of a specific intention underlying the self-representation of the Norman court. In fact, the same idiosyncratic multilingualism can also be seen in several epigraphic inscriptions from the court and in the documents issued by the Norman trilingual chancery (these were in Latin, Arabic and Greek). ${ }^{49}$

In terms of the political function of textile inscriptions, the close resemblance between the alb's inscription and contemporary Norman administrative documents is noteworthy. Not only is the inscription's bilingual form reminiscent of many of the surviving Norman administrative documents, such as the jarìdat al-hudūd from $1182 \mathrm{AD}$ (listing estate boundaries) in Latin and Arabic, but the content is similar too. ${ }^{50}$ Johns' study demonstrates, for instance, that the royal titles used in documents and epigraphy are the same..$^{51}$ Both the Latin and the Arabic inscriptions on the alb list William II's titles and territories, a demonstration of the legitimacy of the king's authority. In the Latin, William II is given the title of 'King of Sicily, of the duchy of Apulia and of the principality of Capua'. ${ }^{52}$ The

\footnotetext{
${ }^{49}$ Multilingual epigraphic inscriptions from Norman Sicily (in Greek, Arabic, Latin and - in one case - Judeo-Arabic) include a foundation inscription from Termini Imerese, an inscription commemorating the creation of Roger II's clepsydra in the Palazzo Reale of Palermo and two funerary slabs. See Johns, 'Die arabischen Inschriften der Normannenkönige Siziliens': 38. On the Norman chancery, see for instance, Kölzer, 'Cancelleria e cultura nel regno di Sicilia'.

${ }^{50}$ Johns, Arabic Administration: cat. 44, 313. The document is transcribed in Cusa, Diplomi greci ed arabi di Sicilia: 179-244.

${ }^{51}$ On the Arabic titles of the Normans, see Johns, Arabic Administration: 268-74. Johns has pointed to possible links (which certainly deserve further attention) between the conception of the Norman epigraphic programmes and the Arabic administration in ibid. See the last chapter in particular: 'Royal dīwān and royal image'.

${ }^{52}$ See note 13. An interesting difference between the Latin and Arabic parts of the inscription appears in William II's identification as the 'supporter of the Imam of Rome' (the pope) and the 'protector of the Christian faith', exclusively in the Arabic part. On this point, see Metcalfe, 'The Muslims of Sicily': 302. This would suggest that the languages were attributed different functions, possibly with different audiences in mind. The bilingual Fayyumic textiles show a similar functional disparity in the two languages used. In fact, Jacques van der Vliet has shown that the Arabic resembles a 'trade mark', which sets the țira $z$ within a politico-economic system, while the Coptic is more explicitly religious and personalised (Van der Vliet, 'In a Robe of Gold': 34-35).
}

- The Medieval History Journal, 15, 2 (2012): 243-268 
Arabic is more fanciful in declaring William the King of Italy, Ankuburda (Lombardy?), Calabria and Sicily. ${ }^{53}$ The similarity between the inscription on the alb and the language of the jarida document, both in their visual recourse to bilingualism and in their specific formulations, reveals the textile inscription to have a distinctly legal, documentary function. A parallel can be drawn here with an eleventh-century silken marriage contract from the Fatimid court (Figure 4). ${ }^{54}$ However, this textile document, with its long embroidered Kufic inscription in superposed lines, is formally very different from the alb and it does not seem to have been part of a garment. Moreover, the alb's inscription does not commemorate

\section{Figure 4}

Marriage contract embroidered on silk, eleventh century Fatimid. Cairo, Museum of Islamic Art

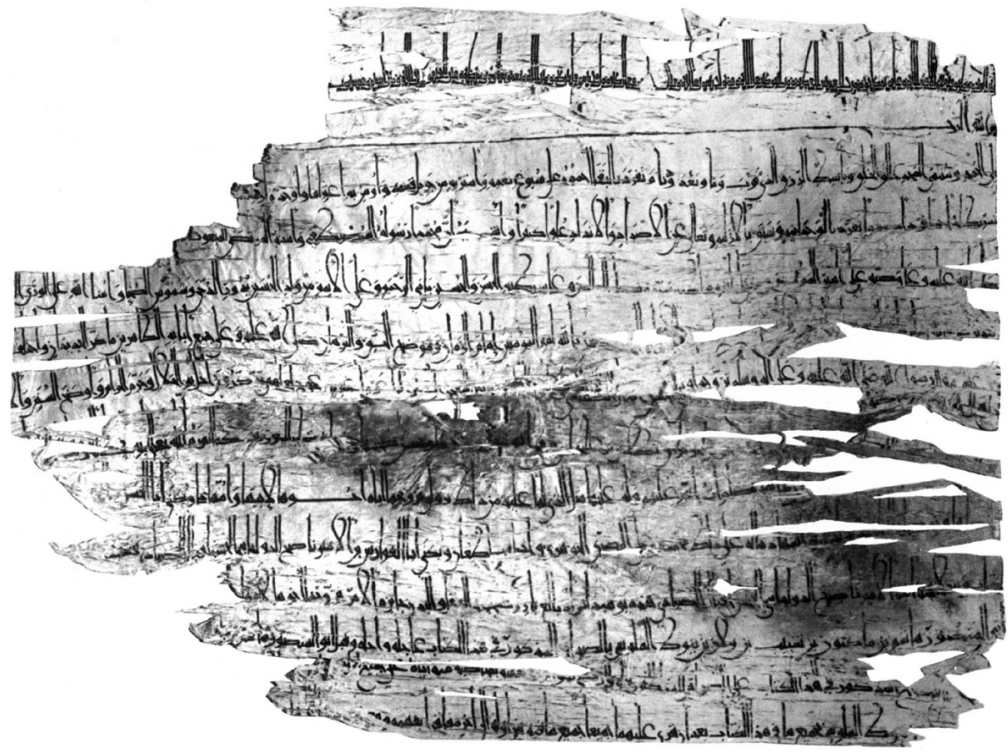

${ }^{53}$ Johns mentions a letter sent by the Fatimid caliph Al-Hāfiz to Roger II, in which a similar list of territorial possessions is given. Johns, 'Die arabischen Inschriften der Normannenkönige Siziliens': 43.

${ }^{54}$ Ragib, 'Un contrat de marriage sur un fragment de soie fatimide'. 
any specific moment considered to be significant in the history of William II's reign, ${ }^{55}$ although it is conceivable that it was commissioned as a demonstrative sign of legal self-authentication in view of an envisaged renewal of the Norman investiture after Pope Alexander III's death in August $1181 \mathrm{AD}^{.6}$

As is shown by the comparison, the alb's bilingual inscription cannot be related to the textile production of the caliphal court. We should therefore see the intention behind its use in Norman Sicily not in terms of the formal transposition of a court aesthetic, but rather, as I have argued, in terms of the legal connotation of its content. The alb's inscription is strongly reminiscent of the Norman administrative documents and reinforces the unifying authority of the king through the written form and legal formulae of two of the languages of his kingdom.

Turning to the mantle, the purely formal juxtaposition of the embroidered inscription with contemporary Fatimid țirāz inscriptions reveals the mantle's script to be slightly old-fashioned. The style of Fatimid tirīa $z$ is usually said to have evolved from an initially very simple script in the tenth century; this gradually became increasingly ornate during the eleventh and twelfth centuries. ${ }^{57}$ The clear ductus of the angular Kufic inscription along the mantle's hem-almost unornamented, with the exception of a few lamalifs and 'ayns - contrasts with the majority of scripts in use on Fatimid tirāz textiles at the same time, which were mostly cursive or floriated. It is difficult, therefore, to relate the mantle's inscription to the contemporary textile trends of Egypt, and this precludes a direct transfer. ${ }^{58}$ It is not clear why such a comparatively obsolete style of writing was chosen for the mantle. However, the clearly drawn form of the inscription strongly suggests that the content was being

${ }^{55}$ William II's accession to the throne, for example, took place in $1166 \mathrm{AD}$, and his marriage to Joan of England in 1177 AD.

${ }^{56}$ Al-Samman, 'Arabische Inschriften': 24.

${ }^{57}$ Marzouk, 'The Evolution of Inscriptions on Fatimid Textiles'. This stylistic classification is based on the observation of general trends and does not take into account that different types of writing could also be used contemporaneously.

${ }^{58}$ Al-Samman points out that the style of the mantle's inscription resembles earlier monumental epigraphy or inscriptions on metal and wooden objects. Al-Samman, 'Arabische Inschriften': 32. Examples of Arabic epigraphy in medieval Sicily can be found in Amari, Le epigrafi arabiche di Sicilia (first edition 1875-85).

- The Medieval History Journal, 15, 2 (2012): 243-268 
emphasised. In fact, the text is written in a type of rhymed Arabic prose called $s a j$ ', a form so unusual on textile inscriptions that the mantle is probably unique.

While no counter-example of a Fatimid textile, let alone a caliphal garment, with a similar inscription in $s a j$ ' is known, the literary form chosen for Roger II's Kufic inscription was highly prestigious. Saj " prose consists of rhythmically structured parts of speech that are connected through rhymes. ${ }^{59}$ The use of this literary form can be traced back to pre-Islamic times, when it was used for divination. Thereafter it fell into disrepute until it re-emerged in the eighth century as the most prominent language of Arabic administration. ${ }^{60}$ From the ninth century on, it was also adopted as the conventional style of orators during Friday prayers $(k h u t b a)$, during which the reigning caliph's name was mentioned and which can be counted as one of the essential markers of caliphal authority. ${ }^{61}$ The choice of this literary form for the mantle's inscription cannot be explained by a specific movement of transfer, nor by referring to a court aesthetic shared across the medieval Mediterranean. Rather-as becomes apparent through the comparative approach - the specific decision to place this type of writing on the royal mantle suggests an awareness of its function and status in Islamic cultures.

Acknowledging such an awareness adds a further aesthetic layer to the interpretation of the mantle's ornamentation, one mediated through sound, rather than visuality. ${ }^{62}$ In Arabic contexts, $s a j{ }^{\prime}$ is intended to be recited aloud before an audience. ${ }^{63} \mathrm{~A}$ similar emphasis on orality and sound on the Norman side can be seen in the arrangement of the letters of the inscription along the mantle's axis of symmetry. Probably, when the mantle was worn, only the central part of the inscription would have been visible on the king's back, while the remainder-except, perhaps, for the beginning and end - would have been partially hidden in drapery folds.

59 'Sadj", EI 2.

${ }^{60}$ Ibid.

${ }^{61}$ Caliphal authority was publicly expressed also through minting coins and inscribing tirāz in his name. Sanders, Ritual, Politics and the City: 5.

${ }^{62}$ On the aesthetic dimension of sound and medieval inscriptions, see, for example, Papalexandrou, 'Echoes of Orality'.

63 'Sadj', EI 2.

The Medieval History Journal, 15, 2 (2012): 243-268 
This central part of the inscription reads: 'wa-bulügh al-amāni wa-l-āmāl / wa țīb al-ayyāmi wa-l-layāl'; or, in the Arabic (Figure 5):

$$
\text { و بلوغ الإماني و الإمال/و طيب الإيام و الليال }
$$

Arabic letters can be extended and shortened almost ad libitum in order to fill a given space. It would have been easy therefore, at this central point, to match the iconography's visual symmetry in the inscription by using the three ornamental interwoven lamalifs (underlined in the Arabic transcription). For a symmetrical visual effect, one of them could have been placed on the central axis, while the other two could have been spaced at equal distances on either side. Instead, the base of the tree representing the axis of symmetry marks precisely the space between the two central parts of the inscription where the enumeration of the qualities of the royal khizāna culminates. I would suggest, therefore, that the comparative approach in this case points to aspects of the Norman inscription which would otherwise be hard to detect. The emphasis on the 'symmetry' of the rhymes of this Arabic literary form, rather than the visual symmetry of the ornamental letters, should be taken into account as an additional aesthetic dimension of the mantle.

If the initial curiosity underlying this article can be expressed simply'why did the Norman kings of Sicily wear Arabic inscriptions?'-the answer is in fact very far from being straightforward. In the absence of conclusive contemporary evidence from the Norman period, the reception of this transcultural ornamental form in art historical discourse thus comes to depend largely upon the methodological approaches used in its

\section{Figure 5}

Central part of the Norman mantle's inscription, detail

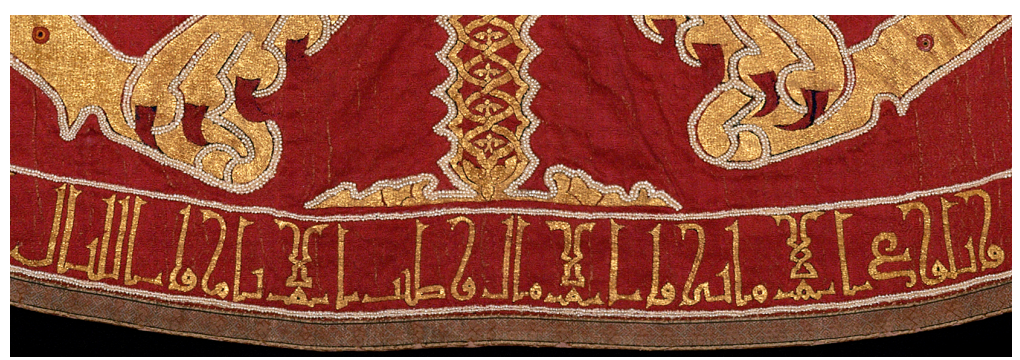

- The Medieval History Journal, 15, 2 (2012): 243-268 
interpretation. Acknowledging a shared Mediterranean aesthetic, as well as emphasising the intention underlying the adaptation of Arabic textile inscriptions to the visual language of the Norman court, is a means of demonstrating the permeability of cultural spheres and overturning the perception that Arabic ornamental inscriptions were confined within firmly drawn cultural - and religious - boundaries. I have argued, however, that approaching the Norman textile inscriptions through the notions of transfer and shared court culture restricts any analysis to formal considerations, and these do not account for the individual content, functions and meanings that the inscriptions had within the specific context of Norman Sicily. In fact, through highlighting parallels and differences, the comparative approach singles out specific choices representative of the Norman visual idiom and of the messages which were intended to be conveyed. In addition, it allows for a contextualisation of forms - visual, and literary in the case of the mantle's inscription - on both sides of a transfer. Of course, I do not wish to suggest that these are the only valid approaches. Nor would I want the sequential presentation of these three distinct, yet interrelated, methods to be understood as a linear, or even hierarchical, progression culminating in the comparative approach. Rather, I would like to point to the benefits of combining them to understanding the complexity of Arabic writing in European contexts, an ornament with manifold forms and facets.

\section{References}

Aanavi, Don. 1968. 'Devotional Writing: "Pseudoinscriptions" in Islamic Art', The Metropolitan Museum of Art Bulletin, vol. 26(9): 353-58.

Abdellatif, Rania, Yassir Benhima, Daniel König and Elisabeth Ruchaud. 2011. 'Introduction à l'étude des transferts culturels en Méditerranée médiévale. Aspects historiographiques et méthodologiques', in Abdellatif et al. (eds), Construire la Méditerranée, penser les transferts culturels: approches historiographiques et perspectives de recherche, Munich: 14-44.

Al-Qalqashandi. 1957. Les institutions des Fâtimides en Egypte. Texte arabe extrait du tome III du "Kitâb Çubh'al-A'châ fì Çinâ 'at al-inchâ" d'après l'édition égyptienne de 1913-1919, Marius Canard (ed.), Algiers.

Al-Samman, Tarif. 1982. 'Arabische Inschriften auf den Krönungsgewändern des Heiligen Römischen Reiches', Jahrbuch der kunsthistorischen Sammlungen in Wien, vol. 78: $7-34$.

Amari, Michele. 1971 (first edition 1875-85). Le epigrafi arabiche di Sicilia: trascritte, tradotte e illustrate, Francesco Gabrieli (ed.), Palermo.

The Medieval History Journal, 15, 2 (2012): 243-268 
Bauer, Rotraud. 2004. 'Zur Geschichte der sizilischen Gewänder, später Krönungsgewänder der Könige und Kaiser des Heiligen Römischen Reiches', in Wilfried Seipel (ed.), Nobiles Officinae: Die königlichen Hofwerkstätten zu Palermo zur Zeit der Normannen und Staufer im 12. und 13. Jahrhundert, Vienna: 85-95.

2004. 'Der Mantel Rogers II. und die siculo-normannischen Gewänder aus den königlichen Hofwerkstätten in Palermo', in Wilfried Seipel (ed.), Nobiles Officinae: Die königlichen Hofwerkstätten zu Palermo zur Zeit der Normannen und Staufer im 12. und 13. Jahrhundert, Vienna: 115-24.

Bellinger, Louisa and Ernst Kühnel. 1952. The Textile Museum Catalogue of Dated Tiraz Fabrics: Umayyad, Abbasid, Fatimid, Washington.

Biermann, Irene. 1980. 'Art and Politics: The Impact of Fatimid Uses of Tiraz Fabrics', Ph.D. thesis, University of Chicago.

- 1998. Writing Signs: The Fatimid Public Text, Berkeley.

Bresc, Henri and Anneliese Nef. 2009. 'Les actes en arabe dans la Sicile d'époque normande', in François Bougard et al. (eds), L'autorité de l'écrit au Moyen Âge (Orient-Occident), conference proceedings (Cairo, 30 April-5 May 2008), Paris: 73-87.

Contadini, Anna. 1999. 'Artistic Contacts: Current Scholarship and Future Tasks', in Charles Burnett and Anna Contadini (eds), Islam and the Italian Renaissance, London: 1-60.

Cusa, Salvatore. 1982 (first edition 1868/82). I diplomi greci ed arabi di Sicilia pubblicati nel testo originale, tradotti ed illustrati, Introduction by Albrecht Noth, Cologne.

Daniele, Francesco. 1784. I regali sepolcri del duomo di Palermo riconosciuti ed illustrati, Naples.

Delluc, Brigitte and Gilles Delluc. 2001. 'Le suaire de Cadouin et son frère: le voile de sainte Anne d'Apt (Vaucluse). Deux pieces exceptionnelles d'archéologie textile', Bulletin de la Société Historique et Archéologique du Périgord, vol. 128: 607-26.

Durand, Maximilien and Simon Rettig. 2002. 'Un atelier sous controle califal identifié dans le Fayoum: le țirāz privé de Ṭuṭūn', in Maximilien Durand (ed.), Egypte la trame de l'Histoire: textiles pharaoniques, coptes et islamiques, exhibition catalogue, Paris: $167-70$.

Bearman, P., Th. Bianquis, C.E. Bosworth, E. van Donzel and W.P. Heinrichs (eds), Encyclopaedia of Islam, Second Edition, Brill.

Enzensberger, Horst. 2007. 'Bamberg und Apulien', in Christine and Klaus van Eickels (eds), Das Bistum Bamberg in der Welt des Mittelalters: Bamberger interdisziplinäre Mittelalterstudien: Vorträge und Vorlesungen, 1, Bamberg: 141-50.

Erdmann, Kurt. 1953. 'Arabische Schriftzeichen als Ornamente in der abendländischen Kunst des Mittelalters', Akademie der Wissenschaften und der Literatur: Abhandlungen der Geistes- und Sozialwissenschaftlichen Klasse, 9, Mainz: 467-513.

Espagne, Michel. 1994. 'Sur les limites du comparatisme en histoire culturelle', Genèses, vol. 17: 112-24.

-1999. Les transferts culturels franco-allemands, Paris.

Feliciano, María Judith. 2005. 'Muslim Shrouds for Christian Kings? A Reassessment of Andalusí Textiles in Thirteenth-Century Castilian Life and Ritual', in Cynthia Robinson and Leyla Rouhi (eds), Under the Influence: Questioning the Comparative in Medieval Castile, Leiden: 101-31.

Flood, Finbarr Barry. 2009. Objects of Translation: Material Culture and Medieval, HinduMuslim Encounters, Princeton University Press.

- The Medieval History Journal, 15, 2 (2012): 243-268 
Fontana, Maria Vittoria. 1999. 'Byzantine Mediation of Epigraphic Characters of Islamic Derivation in the Wall Paintings of Some Churches in Southern Italy', in Charles Burnett and Anna Contadini (eds), Islam and the Italian Renaissance, London: 61-76.

Golombek, Lisa. 1988. 'The Draped Universe of Islam', in Priscilla Soucek (ed.), Content and Context of Visual Arts in the Islamic World, Pennsylvania: 25-50.

Grabar, Oleg. 1997. 'The Shared Culture of Objects', in Henry Maguire (ed.), Byzantine Court Culture from 829 to 1204, conference proceedings (Dumbarton Oaks, April 1994), Washington, DC: 115-30.

- 2005. 'The Experience of Islamic Art', 'The So-called Mantle of Roger II' and 'The Ceiling of the Cappella Palatina', in Irene Biermann (ed.), The Experience of Islamic Art on the Margins of Islam, Los Angeles: 11-59.

Hoffman, Eva. 2001. 'Pathways of Portability: Islamic and Christian Interchange from the Tenth to the Twelfth Century', Art History, vol. 24(1): 17-50.

Jacoby, David. 1991/92. 'Silk in Western Byzantium before the Fourth Crusade', Byzantinische Zeitschrift, vol. 84/5(2): 452-500.

-2004. 'Seide und seidene Textilien im arabischen und normannischen Sizilien: der wirtschaftliche Kontext', in Wilfried Seipel (ed.), Nobiles Officinae: Die königlichen Hofwerkstätten zu Palermo zur Zeit der Normannen und Staufer im 12. und 13. Jahrhundert, Vienna: 61-73.

Johns, Jeremy. 2002. Arabic Administration in Norman Sicily: The Royal Diwan, Cambridge.

—_ 2004. 'Die arabischen Inschriften der Normannenkönige Siziliens: eine Neuinterpretation', in Wilfried Seipel (ed.), Nobiles Officinae: Die königlichen Hofwerkstätten zu Palermo zur Zeit der Normannen und Staufer im 12. und 13. Jahrhundert, Vienna: 37-59.

. 2010. 'Iscrizioni arabe nella Cappella Palatina', in Beat Break (ed.), La Cappella Palatina a Palermo. Mirabilia Italiae, 17, Modena: 353-386.

Knipp, David. 2003/2004. 'Some Aspects of Style and Heritage in the Norman Stanza' in his Art and Form in Norman Sicily, conference proceedings (Rome, 6-7 December 2002), Römisches Jahrbuch der Bibliotheca Hertziana, 35, Munich: 175-207.

Kölzer, Theo. 1990. 'Cancelleria e cultura nel regno di Sicilia (1130-1198)', in Germano Gualdo (ed.), Cancelleria e cultura nel Medio Evo, conference proceedings (Stoccarda, 29-30 August 1985), Vatican: 97-118.

Marzouk, Muhammad Abdelaziz. 1943. 'The Evolution of Inscriptions on Fatimid Textiles', Ars Islamica, vol. 10: 164-67.

Metcalfe, Alex. 2002. 'The Muslims of Sicily under Norman Rule', in Graham Loud and Alex Metcalfe (eds), The Society of Norman Sicily, Leiden: 289-318.

Monneret de Villard, Ugo. 1946. 'La tessitura palermitana sotto i Normanni e i suoi rapporti con l'arte bizantina', in Miscellanea Giovanni Mercati (vol. 3): Letteratura e storia bizantina, Vatican City: 464-89.

O’Connor, Elizabeth. 1980. 'The Star Mantle of Henry II', Ph.D. thesis, Columbia University, New York.

Papalexandrou, Amy. 2007. 'Echoes of Orality in the Monumental Inscriptions of Byzantium', in Liz James (ed.), Art and Text in Byzantine Culture, Cambridge: 139-60.

Ragib, Yusuf. 1980. 'Un contrat de mariage sur un fragment de soie fatimide', Annales Islamologiques, vol. 16: 31-37.

The Medieval History Journal, 15, 2 (2012): 243-268 
Sanders, Paula. 1994. Ritual, Politics and the City in Fatimid Cairo, New York. 2001. 'Robes of Honor in Fatimid Egypt', in Stewart Gordon (ed.), Robes and Honor: The Medieval World of Investiture, New York: 225-39.

Seipel, Wilfried (ed.). 2004. Nobiles Officinae. Die königlichen Hofwerkstätten zu Palermo zur Zeit der Normannen und Staufer im 12. und 13. Jahrhundert, exhibition catalogue (Palermo, December 2003-March 2004 and Vienna, March-June 2004), Vienna.

Serjeant, R.B. 1972. Islamic Textiles: Material for a History up to the Mongol Conquest, Beirut.

Shalem, Avinoam. 1998. Islam Christianized: Islamic Portable Objects in the Medieval Church Treasuries of the Latin West, 2nd revised edition, Frankfurt am Main.

Sokoly, Jochen. 1997. 'Towards a Model of Early Islamic Textile Institutions in Egypt', in Islamische Textilkunst des Mittelalters: Aktuelle Probleme, Riggisberger Berichte, 5, Bern: 115-22.

1997. 'Between Life and Death: The Funerary Context of Tiraz Textiles', in Islamische Textilkunst des Mittelalters: Aktuelle Probleme, Riggisberger Berichte, 5, Bern: 71-78.

Spittle, S.D.T. 1953. 'Cufic Lettering in Christian Art', The Archaeological Journal, vol. 11: $138-52$.

Tronzo, William. 1997. The Cultures of his Kingdom. Roger II and the Cappella Palatina in Palermo, Princeton.

- 2001. 'The Mantle of Roger II of Sicily', in Stewart Gordon (ed.), Robes and Honor: The Medieval World of Investiture, New York: 241-54.

- 2003/04. 'Regarding Norman Sicily: Art, Identity and Court Culture in the Later Middle Ages', in David Knipp (ed.), Art and Form in Norman Sicily, Römisches Jahrbuch der Bibliotheca Hertziana, 35, Munich: 103-14.

Van der Vliet, Jacques. 2006. "In a Robe of Gold": Status, Magic and Politics on Inscribed Christian Textiles from Egypt', in Cäcilia Fluck and Gisela Helmecke (eds), Textile Messages: Inscribed Fabrics from Roman to Abbasid Egypt, Leiden: 23-67.

Werner, Michael and Bénédicte Zimmermann. 2002. 'Vergleich, Transfer, Verflechtung. Der Ansatz der Histoire croisée und die Herausforderung des Transnationalen', in Jürgen Osterhammel (ed.), Modernisierung und Modernität in Asien, Geschichte und Gesellschaft, vol. 28(1): 607-36.

\section{Illustrations}

Figure 1 Norman Mantle, 1133/4 AD. Vienna, Kunsthistorisches Museum, Weltliche Schatzkammer: Inv. Nr. XIII 14. C) Kunsthistorisches Museum.

Figure 2 Norman Alb, late twelfth century. Wien, Kunsthistorisches Museum, Weltliche Schatzkammer: Inv. Nr. XIII 7. (C) Kunsthistorisches Museum.

Figure 3 Shawl with a Coptic-Arabic bilingual inscription, tenth century. New York, Metropolitan Museum of Art: 31.19.13. C bpk/ The Metropolitan Museum of Art.

Figure 4 Marriage Contract embroidered on silk, eleventh century Fatimid. Cairo, Museum of Islamic Art: Inv. Nr. 9381. In Ragib, Yusuf. 1980. 'Un contrat de marriage sur un fragment de soie fatimide', Annales Islamologiques, 16: pl. 13.

Figure 5 Central part of the Norman mantle's inscription, detail. (C) Kunsthistorisches Museum.

- The Medieval History Journal, 15, 2 (2012): 243-268 